\title{
Prøveprosjekt med mammografiscreening i fire fylker; organisering og gjennomføring
}

\author{
Steinar Østerbø Thoresen \\ Prosjektleder dr. med. \\ Kreftregisteret, Montebello, 0310 Oslo \\ Telefon: 22451349 Telefaks: $22451370 \quad$ E-mail: sth@kreftreg.no
}

\begin{abstract}
SAMMENDRAG
Randomiserte kontrollerte studier har vist at systematisk mammografiscreening i aldersgruppen 50 til 69 år reduserer dødeligheten av brystkreft med omlag 30\%. I 1994 ble det av Sosial- og helsedepartementet besluttet å iverksette et prøveprosjekt med mammografi i fire fylker. Prosjektet omfatter kvinner i alderen 50-69 år og skal pågå i fire år med to screeningrunder. Utvalgte fylker er Akershus, Hordaland, Oslo og Rogaland. Det er valgt en fylkeskommunal modell i samarbeid med Kreftregisteret, Statens helseundersøkelser (SHUS) og Statens strålevern. Kreftregisteret har den nasjonale prosjektledelse, mens SHUS har ansvar for invitasjoner, svarbrev samt innkjøp og drift av busser. Prosjektet skal evalueres både fra kostnadsiden og informasjonsvirksomheten. Det utføres to-bilde mammografi med dobbelt tyding. Det første driftsåret var 1996. Oppmøte før purring ligger på omlag 77\%. Det er påvist 337 krefttilfeller. Svulstene er overveiende meget små og uten spredning til lymfeknuter i armhulen. Det har vært få driftsproblemer, og tiltaket er svært godt mottatt blant de inviterte kvinner.
\end{abstract}

Thoresen SØ. Mammography screening in four Norwegian counties: a pilot project. Nor J Epidemiol 1997; 7 (2): 179-182.

\section{ENGLISH SUMMARY}

Organised breast cancer screening by mammography can reduce mortality from breast cancer substantially. In Norway a pilot project in four counties was startet in 1996, including 160000 women in the age group 50 to 69 years. Two-view mammography and double reading are performed. So far the attendance rate is $77 \%$, before reminders are sent to the women. The attendance rate in the mobile units are high. A total of 337 breast cancers have been identified, which is seven out of 1000 screened. The positive predictive value is $13 \%$. The majority of the invasive tumors are small and without nodal involvement. The pilot project is scheduled for four years and will also be evaluated form the cost/benefit side.

\section{INNLEDNING}

Brystkreft er den klart hyppigste kreftform blant kvinner i den vestlige verden. I Norge rammes 2100 kvinner av sykdommen hvert år (1). Brystkreft utgjør om lag $23 \%$ av alle nye krefttilfeller hos kvinner. Årlig dør nesten 800 norske kvinner av sykdommen (2). Brystkreft er en av de viktigste årsaker til tapte leveår hos kvinner opptil 65 år. Vel 20000 norske kvinner lever i dag med diagnosen brystkreft - nesten alle er operert.

Av størst betydning for overlevelsen er svulstens størrelse og eventuell spredning til armhulens lymfe- knuter. Kvinner med små svulster uten spredning har en god prognose, med 5-års relativ overlevelse på om lag $90 \%$ (1).

Ved en systematisk masseundersøkelse med mammografi kan sykdommen oppdages i tidligere stadier. Randomiserte kontrollerte studier fra Sverige viser at screeningprogram av høy kvalitet kan redusere dødeligheten av brystkreft med om lag $30 \%$ i aldersgruppen 50-69 år etter omlag 7 års oppfølgning (3).

Denne artikkelen gir en gjennomgang av status for mammografiscreening i Norge med hovedvekt på organisering og gjennomføring. 


\section{HISTORIKK}

Mammografiscreening som systematisk masseundersøkelse i offentlig regi ble først drøftet i full bredde etter at Tabar og medarbeidere offentliggjorde sine resultater fra to svenske fylker i 1985 (4). Senere er disse resultatene bekreftet $\mathrm{i}$ en rekke andre studier, inkludert oppfølgingsstudier i Sverige (3).

En arbeidsgruppe la fram sin utredning i NOU 1987:7 Mammografiscreening i Norge. Arbeidsgruppen konkluderte med at man under bestemte forutsetninger bør gjennomføre nasjonal screening med mammografi i Norge. Dette kunne best gjøres med toårige intervaller i aldersgruppen 50-74 år, og under tvil kom man til at mammografiscreening også burde tilbys kvinner i aldersgruppen 40-49 år med årlige intervaller. Gruppen konkluderte videre med at en forutsetning for mammografiscreening er godt utbygd klinisk mammografi (5).

I 1989 ble det avholdt en nasjonal konsensuskonferanse om mammografiscreening i NAVF-regi. Konferansen konkluderte med at man ikke anbefalte masseundersøkelse innført på det daværende tidspunkt, fordi man ville vente på resultatet av de pågående vurderingene av de svenske undersøkelsene (6).

I 1990 ble så NOU 1987:7 oppdatert av den samme arbeidsgruppen, som i hovedsak fastholdt sine tidligere anbefalinger, men foreslo screening for aldersgruppen 50-69 år. Videre har det vært fylkeskommunale utredninger i Oslo og Akershus som har anbefalt oppstart av screening.

Samtidig med at det har trukket noe ut med en nasjonal offentlig mammografiscreening i Norge, har det vokst fram en ikke ubetydelig screeningvirksomhet i privat regi. Beregninger har vist at det i 1992 ble tatt om lag 100000 mammografiundersøkelser årlig i Norge utenfor det offentlige helsevesenet. Av disse er om lag 40000 primærbildetaking uten forutgående henvisning fra lege. Denne såkalte villscreening foregår uten faglig evaluering og ofte med offentlige midler.

De fleste land i Vest-Europa har enten startet systematisk mammografiscreening eller har fattet vedtak om å starte slik screening. I Sverige eksisterer det nå tilbud om offentlig mammografiscreening i alle fylker. Finland og Island har startet screening i alle sine kommuner. Danmark har startet screening i noen amt.

Den Norske Kreftforening stilte i 1991 fem mill. kroner til disposisjon for å planlegge og starte opp forsøksdrift med offentlig mammografiscreening.

Sosialdepartementet ba i 1992 Helsedirektoratet om å utarbeide et konkret opplegg for fors $ø$ ksdrift med mammografiscreening i ett eller flere fylker. Helsedirektoratet fikk utarbeidet en prosjektplan høsten 1992. Som vedlegg til planen utarbeidet Statens helseundersøkelser en beskrivelse av hvordan et slikt screeningopplegg kunne gjennomføres.

Departementet anså at det var behov for ytterligere utredning, og oppnevnte i juni 1993 en referanse- gruppe for prøveprosjekt med masseundersøkelse av brystkreft ved mammografi.

Referansegruppen leverte sin prosjektplan 21. juni 1994 til Sosial- og helsedepartementet. Planen ble senere godkjent av departementet (7). I prosjektplanen er det lagt fram forslag til iverksetting av prøveprosjekt med masseundersøkelse mot brystkreft ved mammografi. Prøveprosjektet foreslås lagt til tre prøvefylker og omfatte kvinner i aldersgruppen 50 til 69 år. Prosjektet skal pågå i fire år og omfatte to screeningrunder.

For 1994 bevilget staten 24 mill. kroner til prøveprosjekt med mammografiscreening. Hovedparten av midlene ble overført til 1995. Mesteparten av 1995 gikk med til å planlegge prosjektet. Dette bestod blant annet i å utarbeide en konkret framdriftsplan, IT-plan og kravspesifikasjon og anbud for innkjøp av mobile enheter.

\section{MÅLENE FOR PRøVEPROSJEKTET}

Hovedmålene for prøveprosjektet er å finne fram til arbeidsmåter som kan forventes å redusere dødeligheten av brystkreft med 30\% i prøvefylkene, samt å prøve ut de organisatoriske, økonomiske og faglige sider ved en brystkreftscreening i prøvefylkene. Basert på erfaringene fra første screeningrunde i prøveprosjektet, kan man etter to år anslå konsekvensene av brystkreftscreening på landsbasis og ta en avgjørelse om eventuell igangsetting av et nasjonalt screeningprogram.

\section{VALG AV PRØVEFYLKER}

Under vurderingen av hvilke fylker som kunne være aktuelle, har det vært vektlagt at prøvefylkene må kunne støtte kompetanseoppbyggingen på landsbasis. Slik kompetanseoppbygging er en forutsetning for at programmet etter hvert også kan startes i andre fylker. I denne sammenheng har det vært viktig å velge fylker som har tilstrekkelig antall kvinner $i$ aldersgruppen 50-69 år til å få erfaringsgrunnlag for en eventuell gjennomføring på landsbasis. Det har også vært stilt visse faglige krav til prøvefylkene. På denne bakgrunn valgte man å anbefale at Akershus, Hordaland og Rogaland blir prøvefylker. Oslo ble foreslått assosiert til prøveprosjektet, og kunne dermed gis en begrenset økonomisk støtte.

\section{VALG AV MODELL FOR SCREENINGEN}

En rekke modeller for gjennomføringen av screeningen har vært utredet. Blant disse inngår en sentralisert modell (SHUS-modell) og en fylkeskommunal modell. Referansegruppen tilrådde ut fra en samlet vurdering at det benyttes en modell hvor hovedansvaret legges til fylkeskommunene, men hvor enkelte oppgaver utføres nasjonalt. Den nasjonale prosjektledelsen ble foreslått lagt til Kreftregisteret, og forutsettes å ha ansvar for 
nasjonale retningslinjer, evaluering og kvalitetssikring, samt å koordinere datautvekslingen. Statens helseundersøkelser har ansvaret for invitasjoner, svarutsendelse og koordinering av mobile bildetakingsenheter. Det ble også anbefalt at Statens strålevern har en sentral rolle innen rådgivning og koordinering for den stråletekniske siden av prosjektet.

En styringsgruppe med assisterende fylkeslege Torill Hagerup-Jenssen som leder har det overordnede ansvar for prøveprosjektet, mens en referansegruppe med representanter fra alle faggrupper og fylker har faglig rådgivningsansvar overfor prosjektleder og styringsgruppen.

Videre har informasjonsgruppen ansvar for det totale informasjonsopplegg i prosjektet, mens regjeringens kostnadberegningsutvalg under ledelse av professor Arild Hervik har ansvar for kostnadsanalysen. Dette er en viktig del av prosjektet med konsekvenser for eventuelt senere utvidelse til andre fylker.

\section{KVALITETSSIKRING}

Erfaringer fra brystkreftscreening $i$ andre land har vist at kvalitetssikring er svært viktig for at programmene skal oppnå forventet reduksjon i dødelighet av brystkreft. Kvalitetssikringen bør utføres i hvert enkelt ledd i screeningprosessen, og referansegruppen foreslås tillagt en rådgiverfunksjon i forhold til kvalitetssikringen. Det ble i 1995 utarbeidet en kvalitetssikringsmanual for prosjektet. Denne inneholder generelle retningslinjer og målsettinger, samt egne manualer for alle faggrupper og berørte institusjoner. Manualen ble ferdigstillet ultimo desember 1995 og skal oppdateres årlig.

Blant de viktigste aspekter i manualen er vedtaket om to mammografibilder av hvert bryst og dobbelt uavhengig tyding av hvert bilde.

\section{STATENS HELSEUNDERSØKELSER}

Statens helseundersøkelser (SHUS) har ansvar for innkjøp og drift av tre busser, samt planlegging og utsendelse av invitasjoner og negativt svarbrev. Bussene har på alle måter fungert etter målsettingen. Det har ikke vært driftsstopp eller nevneverdige problemer av annen karakter. Både inviterte kvinner og radiografer har uttrykt tilfredshet med bussene som enhet for primærscreening. Fremmøte i kommuner med buss som screeningenhet har vært meget bra (80\%).

Invitasjonsbrev og svarbrev er sendt ut etter målsetting og tidsfrister. Små forsinkelser av svarbrev har vært observert. Dette har som oftest skyldtes forsinket edb-overføring.

Fram til 31.12.96 har SHUS sendt ut 63635 invitasjonsbrev og 35860 svarbrev. Fra høsten 1996 startet man med purringer til ikke-møtte, og det var fram til 31.12 .96 sendt ut 1343 purrebrev.

\section{STATENS STRÅLEVERN}

Statens strålevern skal spesielt være ansvarlig for rådgivning og koordinering innen

1. teknisk kvalitetskontroll

2. optimalisering av bildekvalitet/stråledose

3. opplæring innen teknisk kvalitetskontroll, bildekvalitet, strålefysiske prinsipper etc.

4. nordisk og internasjonalt samarbeid om kvalitetskontrollrutiner

5. nye bildediagnostiske metoder

Strålevernet har utført teknisk og strålehygienisk kontroll etter oppsatte rammer. Det er gitt regelmessige skriftlige tilbakemeldninger til fylker og prosjektleder. Forholdene er i alle fylker funnet tilfredsstillende både vedrørende bildekvalitet og strålehygiene.

\section{KREFTREGISTERET}

Kreftregisteret har den nasjonale prosjektledelse med ansvar for oppbygging, gjennomføring og evaluering av prøveprosjektet. Videre har instituttet hovedansvar for IT-delen og informasjonsvirksomheten i prosjektet. Kreftregisteret samler inn alle viktige data fra fire provefylker og statsintsitusjonene. Kreftregisteret er også sekretariat for styringsgruppen og referansegruppen.

\section{INFORMASJONSTEKNOLOGI}

I et screeningprogram av denne typen er det helt nødvendig å benytte elektronisk databehandling. For å muliggjøre evaluering og kvalitetssikring på nasjonalt plan, er det opprettet en nasjonal database som lagrer informasjon om invitasjoner, primærbildetaking og oppfølgende undersøkelser. Hvert mammografisenter vil ha en tilsvarende database som er begrenset til det geografiske området som mammografisenteret har ansvar for.

Kreftregisteret har hatt ansvar for IT-utvikling i mammografiprosjektet. Man engasjerte Kompetansesenteret for IT i Helsevesenet (KITH) til å utforme en IT-plan som senere dannet grunnlag for kravspesifikasjonen for IT-delen. Alt IT-utstyr ble kjøpt inn sentralt via utsendelse av anbud etter EØSreglementet. Det har således vært felles innkjøp for alle prøvefylker og statsinstitusjonene.

\section{AKERSHUS}

Befolkningen i Akershus betjenes av to busser med fylkets mammografisenter på Det Norske Radiumhospital. Oppfølgning av kvinnene (etterkontroll) er delt mellom Sentralsykehuset i Akershus og Det Norske Radiumhospital. Mammografiscreeningen startet med første buss 12.02.96 for å betjene de østlige deler av Bærum. Bussen har siden betjent Nesodden, Vestby og 
Frogn kommune. Buss nr. to ble mottatt 10.04.96. Den ble først plassert i Lørenskog, og har siden betjent Hurdal, Eidsvoll, Aurskog-Høland og Nannestad. Frammøtet i de forskjellige kommunene har vært meget varierende. Sannsynligvis på grunn av til dels utbredt "villscreening" har frammøtet vært lavest i Bærum. Frammøtet har også vært lavt i Lørenskog, mens de mer perifere kommunene har hatt et frammøte på over $80 \%$.

\section{HORDALAND}

Hordaland startet prøveprosjektet med mammografiscreeningen av Bergen og Askøy 15.01.96 i stasjonær enhet. Fra 02.05.96 har det også vært screenet i buss i øvige Hordaland. Fylkets mammografisenter er lagt til Haukeland Sykehus, der det også er en screeningenhet. Fra 15.01.96 fram til 31.12.96 har det vært invitert 14664 kvinner, og 11 776, dvs. 80,3\%, har møtt opp. Det har vært dårligst oppmøte i Bergen, hvor oppmøteprosenten for 1996 var 75,9\%. Høyest oppmøte finner man i Ullensvang kommune, hvor 90,8\% av de inviterte har møtt. Oppmøte ved den mobile enheten har ligget over $80 \%$.

\section{ROGALAND}

Rogaland har hatt faste screeningenheter i Stavanger og Haugesund. Kvinnene har til dels hatt meget lang reisevei (opptil $90 \mathrm{~min}$. en vei). Oppmøtet i Rogalands enheter har vært meget godt, og over målsettingen på $80 \%$. Noen kommuner har ligget godt over $90 \%$. Samlet sett har frammøtet i Stavanger vært $87 \%$ og i Haugesund $81 \%$. Fylkets mammografisenter ligger ved Sentralsykehuset i Rogaland. All etterkontroll foregår her. Til sammen er 14849 kvinner invitert i 1996, og av disse har 12799 møtt opp. Dette gir en oppmøteprosent i fylket på $86,2 \%$.

\section{OSLO}

Oslo har en stasjonær screeningenhet på Majorstua som dekker hele byen. Screening startet primo januar 1996. Fram til årsskiftet 1996/97 ble 16656 kvinner invitert og 11070 har møtt opp. Dette gir en oppmøteprosent på $66,5 \%$. Det er drevet intens informasjonsvirksomhet $\mathrm{i}$ flere bydeler, uten at dette synes å påvirke oppmøtet.

Bedømt etter foreløpige tall fra frammøteskjemaene har en stor del av kvinnene i Oslo benyttet seg av det private screeningtilbudet som eksisterer $\mathrm{i}$ byen. Dette er trolig den viktigste forklaringen på det lave frammøtet. Av kvinnene som har reservert seg pga. nylig tatt/går årlig til mammografi angir 3 av 4 at de vil delta i neste screeningrunde.

\section{SAMLET VURDERING AV FØRSTE DRIFTSÅR}

1996 representerer det første året med tilnærmet full drift i alle fire fylker. Til sammen er 60147 kvinner invitert og 46329 har møtt opp, hvilket gir en samlet frammøteprosent på $77 \%$ før purringen er kommet skikkelig i gang. Det betyr sannsynligvis at målsettingen om $80 \%$ frammøte er innen rekkevidde. De foreløpige tall viser at det er påvist 337 tilfeller av brystkreft, hvilket gir en deteksjonsrate på 7 pr. 1000 . Den samlede positive prediktive verdi ligger på 14\%. Blant viktige tidlig-indikatorer kan nevnes at hele $67 \%$ av svulstene er mindre eller lik $15 \mathrm{~mm}$ og at kun $18 \%$ av kvinnene har fått påvist spredning til lymfeknuter $\mathrm{i}$ armhulen. Dette er svært gode resultater, og langt bedre enn målsettingen som ville gitt en forventet mortalitetsreduksjon på $30 \%$.

Den endelige evaluering vil komme etter avsluttet annen screeningrunde og vil omfatte epidemiologiske og kliniske data, samt en komplett kostnadsanalyse og vurdering av informasjonsvirksomheten.

\section{REFERANSER}

1. Cancer in Norway 1993. Kreftregisteret, 1996.

2. Dødsårsaker 1993. Statistisk Sentralbyrå, 1994.

3. Nystrøm L, Rutquist LE, Lindgren M, et al. Breats cancer screening with mammography; overview of Swedish randomized studies. Lancet 1993; 341: 973-978.

4. Tabar L, Fagerberg G, Gad A, et al. Reduction in mortality from breast cancer after mass screening with mammography. Lancet 1985; 1: 829-832.

5. Mammografiscreening i Norge. NOU 1987;7. Oslo, Universitetsforlaget, 1987.

6. Mammografiscreening. Konsensusuttalelse. Tidsskr Nor Lageforen 1989; 109: 1038-1039.

7. Prøveprosjekt med mammografi 1994. Prosjektplan. Oslo, 1994. 